\title{
When Consumer Behavior Goes Bad: An Investigation of Adolescent Shoplifting
}

\author{
DENA COX \\ ANTHONY D. COX \\ GEORGE P. MOSCHIS*
}

\begin{abstract}
Shoplifting is a troubling and widespread aspect of consumer behavior, particularly among adolescents, yet it has attracted little attention from consumer researchers. This article reports and interprets findings on the pervasiveness of shoplifting among adolescents, the characteristics that distinguish adolescent shoplifters from their nonshoplifting peers, and adolescents' views regarding the reasons for this behavior. Our findings contradict some popular stereotypes concerning the typical shoplifter and suggest some rethinking about adolescents' reasons for shoplifting.
\end{abstract}

$\mathrm{S}^{\mathrm{n}}$ hoplifting is one of the most troubling and least understood aspects of consumer behavior. Individual acts of consumer theft may be viewed as minor, "sporadic pilfering"' (Cameron 1964), but their aggregate impact is enormous. Retailers lose an average (at retail) of about 2 percent of their sales to merchandise shortages, about 40 percent of which are attributed to shoplifting (i.e., the theft of merchandise, during store hours, by someone who is shopping or pretending to shop; Baumer and Rosenbaum 1984). Given total U.S. retail sales of $\$ 1.45$ trillion (Berman and Evans 1989), this would imply that American consumers steal about $\$ 11.6$ billion in merchandise a year-more than, for example, they purchase from direct sales companies (Peterson, Albaum, and Ridgway 1989).

The costs of shoplifting are also borne by honest consumers. Stores often increase their prices to cover anticipated merchandise "shrinkage," creating what one writer calls "a hidden tax of $\$ 150$ [per year] on each family in the United States" (Wilkes 1978). In addition, consumers must endure the delays and intrusions brought on by the locks, tags, and surveillance that now pervade the retail market place.

At first glance, the shoplifting phenomenon might seem a more appropriate topic for criminologists than for consumer researchers. However, shoplifting is not

* Dena Cox and Anthony D. Cox are assistant professors of marketing, Indiana University School of Business, 801 West Michigan Street, Indianapolis, IN 46202-5151. George P. Moschis is professor of marketing, Georgia State University, College of Business Administration, University Plaza, Atlanta, GA 30303. The authors thank John O. Summers, Donald Granbois, Ronald D. Anderson, and three anonymous reviewers for their helpful comments, and Jackie Watson for her skillful typing of this manuscript. limited to a small criminal subculture; instead, it is a startlingly common method of consumer product acquisition. Evidence suggests that as many as 60 percent of consumers have shoplifted at some time in their lives (Klemke 1982; Kraut 1976) and that more than 200 million shoplifting incidents occur annually (Baumer and Rosenbaum 1984). Although a few shoplifters are professional thieves (see, e.g., Klokis 1985), the vast majority appear to be amateurs in that their activity is sporadic, they typically have no known history of criminal activity, and they steal for their own consumption rather than for resale (Baumer and Rosenbaum 1984; Cameron 1964). The pervasiveness of consumer theft has prompted one investigator (Kraut 1976) to label it a "folk crime."

Shoplifting is a particularly common behavior among adolescent consumers. Roughly 40 percent of apprehended shoplifters are reported to be adolescents (Baumer and Rosenbaum 1984), and anonymous self-report studies (e.g., Klemke 1982) also indicate widespread shoplifting among adolescents.

Despite the enormity of the shoplifting phenomenon and its great potential interest to consumer researchers, it has attracted remarkably little attention in the consumer behavior literature. For example, Cole (1989) could find only five studies of shoplifting and consumer fraud in the consumer behavior literature over the past 16 years. Ironically, researchers have been particularly neglectful of the consumers who shoplift the most: adolescents. There has been only one major study of adolescent shoplifting, conducted by Klemke (1982). Klemke collected self-reports from students in four small-town high schools in the Pacific Northwest, focusing primarily on the demographic traits of adolescent shoplifters (some of which we will discuss later). 
Our study will build on previous research on adolescent shoplifting and attempt to provide a richer understanding of this phenomenon. Like Klemke, we will examine how adolescent shoplifters differ from their nonshoplifting counterparts. As we will see, this issue is both controversial and important, since several popular explanations of shoplifting have been based on (often questionable) beliefs concerning who shoplifts. However, we will also extend Klemke's work in several respects.

First, we go beyond demographics and explore the possible reasons for adolescent shoplifting. While several social scientists (e.g., Cameron 1964; Moore 1983) have expressed their views on adolescents' reasons for shoplifting, there are very few data on what the adolescents themselves perceive these reasons to be. We present such data.

Second, we examine whether adolescent shoplifting is an isolated phenomenon or part of a pattern of youthful misbehavior. Further, rather than limit our study to high school students (as Klemke did), we draw our respondents from the full range of adolescence, roughly grades 7-12.

Ultimately, we address the most basic questions regarding shoplifting: Why is this behavior so common among seemingly respectable consumers, and why does it appear to peak among adolescent consumers? By placing our findings in the context of relevant work from criminology, psychology, and consumer behavior, we seek to develop some well-grounded interpretations that can guide future theory and research on this important aspect of consumer behavior.

\section{METHOD}

\section{Sample}

Most shoplifting studies have relied on data collected from apprehended shoplifters. Though these data are often conveniently available (in either store or law enforcement archives), they have some serious limitations. Only a small percentage of shoplifters are caught (Griffin [1984] estimates one in every 20-40), and they are probably not representative of shoplifters as a whole. For example, store biases in surveillance and apprehension may result in an underreporting of juvenile and affluent shoplifters (Cameron 1964; Klemke 1982; Robin 1963; see also Hardt and Hardt 1977). In addition, the questioning of apprehended shoplifters is often conducted under high pressure and is likely to be distorted by the shoplifter's desire to "save his skin" (Klemke 1982). Finally, studies of apprehended shoplifters typically lack a control group of comparable nonshoplifters.

To avoid these biases and limitations, we drew respondents from the general population of adolescents, allowing shoplifters to identify themselves anonymously. (For good discussions of this approach, see Hardt and Hardt 1977; Klemke 1982.) Over a period of about four months, questionnaires were distributed in nine middle and high schools located in the state of Georgia. With the guidance of the school superintendent in a very large, diverse county, we selected schools representing a variety of socioeconomic groups and community types (i.e., urban, suburban, and nonurban). Within each school, the questionnaires were administered solely in courses that were required for all students (e.g., health, state history, economics). Questionnaires were administered to a total of 1,750 adolescents. After excluding 58 because of excessive missing data, 1,692 usable questionnaires were obtained. The respondents were about evenly divided between male (51.5 percent) and female (48.5 percent) adolescents. They had a mean family occupational status of 51.2 on Duncan's (1976) scale (based on father's occupation; mother's occupation was used in father-absent homes), which was somewhat higher than the national average of about 41.0 (see, e.g., Featherman and Hauser 1978). However, they represented quite a diversity of backgrounds. Respondents' scores ranged from 2 (e.g., a coal mine laborer) to 96 (e.g., a dentist) and had a standard deviation of 21.8. Fifty-eight percent of the respondents were in middle school (grades 7 and 8), and 42 percent in high school (grades 9-12). The sample was 58.9 percent white, 36.7 percent black, and 4.4 percent from other races. The total percentage of nonwhites (41.1 percent) was higher than for the state of Georgia (27.7 percent) and the United States as a whole (16.9 percent; U.S. Department of Commerce 1983).

\section{Procedure}

Because of the sensitive topic, respondents were given several assurances prior to filling out the questionnaire. First, their teachers (by prior arrangement) were absent. Second, the cover sheet of the questionnaire told them, "Since you are not asked to put your name on this questionnaire, NO ONE WILL KNOW WHO YOU ARE." This was also read aloud by the researcher. Finally, they were told in advance that their questionnaires would be returned to an enclosed box, which would then be stirred by a student volunteer.

After the completed questionnaires were returned to the box and stirred, the respondents were thanked for their participation. In a debriefing held with a subsample of participants, no significant apprehension about the survey was noted. Upon probing, no respondents could think of any way that responses could be traced back to an individual.

\section{Measures}

Shoplifting behavior was measured by asking respondents how often ("several times," "few times," 
or "never") they had shoplifted each of 10 types of products during the past year. The products were candy and sweets, records and tapes, sporting equipment, clothing, health items, school supplies, books and magazines, toys, drugs and alcohol, and cigarettes. Previous research (May 1978) suggested, as did the authors' pretest survey of 151 adolescents, that these products account for almost all adolescent shoplifting.

Family occupational status was measured according to Duncan's (1976) scale of occupational status. Respondents were asked to write "the kind of jobs their mothers and fathers do." Other demographic measures included age (grade in school) and sex.

Perceived reasons for adolescent shoplifting were measured by having respondents state their extent of agreement (on a five-point scale ranging from "very much agree' to "very much disagree") with 15 possible reasons that adolescents may shoplift (e.g., "they need the items badly," "they want to please their friends," "they want to see if they can get away with it"). These items covered a range of possible reasons for adolescent shoplifting, focusing primarily on the three types most commonly mentioned in previous research: experiential, social, and economic. The experiential aspect of adolescent shoplifting has emerged in several studies (e.g., Belson 1975; Klemke 1982). A Gallup poll (Fact Sheet 1980) revealed that 68 percent of admitted juvenile shoplifters felt the "kicks" from shoplifting were a more important motivation than the need for money. The notion that adolescents shoplift in response to peer pressure has also been mentioned by several writers (e.g., Johnson 1979), and Moore (1983, p. 1111) speculates that shoplifting may be "a game among middle class youth . . . for status among peers." The facts that shoplifters tend to know other shoplifters and to be apprehended in groups are sometimes cited as evidence of adolescent peer pressure to shoplift. The economic reason for shoplifting was mentioned by Klemke (1982) and especially by Kraut (1976), many of whose college-age shoplifters seemed to view shoplifting as simply the ultimate "bargain."

Rule-breaking behavior was measured by asking respondents the frequency (on a 1-5 scale) with which they engaged in 10 such behaviors (e.g., "smoking where not allowed," "lying to teacher," "copying homework from a friend," "disobeying parents," "swearing and cursing"). This 10-item scale had a coefficient alpha of 0.70 .

Following the guidelines set forth by Sudman and Bradburn (1974), the questions were carefully worded to minimize perceived personal threat. For example, questions were prefaced by such phrases as "We are interested in your thoughts about a number of things people your age often do" and "Below are listed a number of situations that teenagers often experience." It has been shown (e.g., by Blair et al.
FIGURE 1 SHOPLIFTING AND GRADE IN SCHOOL

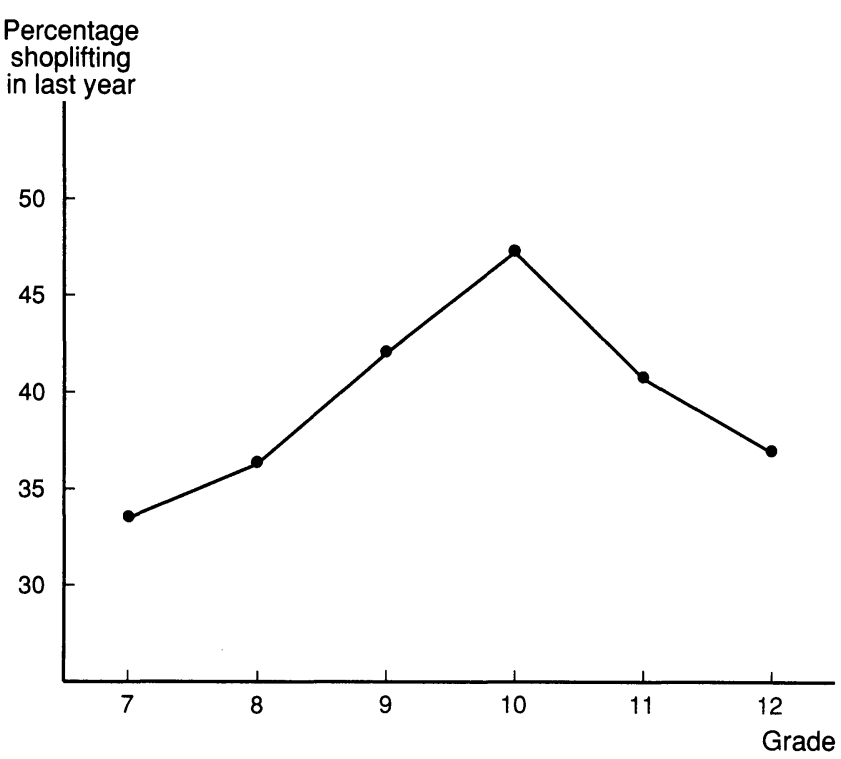

1977) that such prefatory statements tend to increase the accuracy of self-reports regarding sensitive behaviors.

In the following sections, we will first discuss the incidence of reported shoplifting among our adolescent respondents. Next, we will discuss what adolescents themselves perceive as the reasons behind adolescent shoplifting. Finally, we will explore demographic and behavioral differences between shoplifting and nonshoplifting adolescents. In each section, we will report our findings and then interpret and discuss the implications of these findings.

\section{RESULTS AND INTERPRETATION}

\section{Incidence of Shoplifting among Adolescents}

Of the total sample of 1,692 adolescents, 632 (or 37 percent) had shoplifted at least once in the past 12 months. In comparison, 22 percent of Klemke's (1982) high school students reported shoplifting since the beginning of the school year (a shorter time period).

As can be seen in Figure 1, the percentage of our respondents who reported recent shoplifting rose steadily from the seventh through the tenth grade (47 percent of the tenth graders reported shoplifting in the past year) and then declined thereafter. If we divide respondents into three age groups (grades 7 and 8 , grades 9 and 10 , and grades 11 and 12), we find the incidence of shoplifting among middle adolescents (44 percent) higher than among either early ( 35.5 percent) or late (38.8 percent) adolescents. These results are statistically significant $\left(\chi^{2}=7.76, p<.05\right)$. 
Overall Prevalence of Consumer Shoplifting. It appears from our own and previous studies that a large percentage of consumers shoplift at some time in their lives. Retrospective questions by Klemke (1982) and Kraut (1976) suggest that as many as 60 percent of consumers may have shoplifted. Further, both law enforcement (U.S. Federal Bureau of Investigation 1988) and retail industry statistics (Merchandising and Operating Results of Department and Specialty Stores 1988) indicate that shoplifting continues to increase.

Why do so many consumers steal from retailers? While this phenomenon is disturbing, we need not conclude that all or even most of these people are truly criminals. Nettler (1989, p. 37) observes that many people are contingently honest; they behave honestly most of the time, but will occasionally slip into dishonesty if the circumstances are right. Such circumstances include temptation, ability to rationalize, and perceived low risk of apprehension and punishment.

The first circumstance is temptation. While professional thieves are often obsessed with theft, starting each day planning what and how they will steal (see, e.g., Pistone and Woodley 1988), the thought of theft may not occur to the contingently honest person prior to stumbling upon a particularly tempting opportunity (Nettler 1984, 1989).

A second factor conducive to theft is the ability to rationalize or deny it. In early studies of white-collar crime, Cressy (1950) and Sutherland (1949) found that most offenders had a strong need to justify their behavior. Many claimed that they intended to repay the money, that their rich employer wouldn't miss it, or that, being underpaid, they were simply taking what was rightfully theirs. Similarly, Cameron (1964) observed that apprehended shoplifters generally did not think of themselves as thieves or view their activity as a real crime. Clinard and Meier (1979) note that shoplifters often argue that "I buy a lot here anyway" or that the stores expect people to steal.

It may be easiest to rationalize theft when it is targeted at large, impersonal organizations. Smigel (1970, p. 15) found that "if obliged to choose, most individuals would prefer to steal from, and be more approving of others stealing from, large scale, impersonal . . . organizations." Smigel's respondents felt that large institutions could most easily absorb the losses, that they "allowed for it" (through raised prices and insurance), or that they deserved it, since "they cheat you too." Nettler $(1984$, p. 3) notes that guilt-free theft is easiest "if the victims are not visible persons, but invisible collections of anonymous others."

A third factor conducive to theft is perceived low risk. As one might expect, contingently honest people are more likely to steal when they perceive there to be a small chance of being caught and punished (Cole 1989; Johnson 1979; Nettler 1984, 1989).

If one compares these three conditions (temptation, ease of rationalization, and perceived low risk of apprehension) to the characteristics of most modern retailers, the pervasiveness of consumer shoplifting suddenly becomes less puzzling. To begin with, retail stores are designed with the express purpose of tempting customers with merchandise; in the words of Ewen and Ewen (1982), they are "theaters of goods." In fact, Russell (1973) has argued that stores' efforts to increase impulse buying (e.g., enticing displays that encourage customers to handle merchandise) may also increase shoplifting. It may not be coincidence that the same types of merchandise (e.g., costume jewelry) are often listed both as frequent impulse purchases (Bellenger, Robertson, and Hirschman 1978) and as frequently shoplifted items (Merchandising and Operating Results 1987).

In addition, retailers are increasingly large, impersonal institutions. The continuing growth of national chains at the expense of local, family-owned stores may facilitate guilt-free consumer theft. Several decades ago, the sociologist Stone (1954) found that some consumers actually felt protective of stores owned by local individuals, but did not feel this way about large chains.

Finally, retail theft may be perceived as relatively risk free. As noted earlier, only about one in every 30 shoplifters is apprehended by store officials, and many stores are reluctant to press charges, especially for small thefts or those committed by young offenders (Baumer and Rosenbaum 1984).

As retail stores increasingly adopt self-service strategies (Berman and Evans 1989), they become even more attractive targets for consumer theft. A lack of personal service may make stores seem faceless, making shoplifters feel that there is no specific victim for their crime. In addition, self-service operations typically have more difficulty monitoring customers' activity, thereby reducing shoplifters' risk of detection and punishment (Baumer and Rosenbaum 1984).

Shoplifting's Peak among Adolescents. A second finding is that shoplifting activity appears to exhibit a peak in middle adolescence. As noted previously, about 40 percent of apprehended shoplifters are adolescents, and both our and Klemke's (1982) self-report studies indicated high rates of shoplifting among adolescents, particularly middle adolescents. Klemke's data, like ours, showed a decline in shoplifting in late high school, a decline that Kraut's (1976) findings suggest continues throughout the college years. For decades, official crime statistics have indicated that the commission of property crime in general peaks among 16-17-year-olds, then steadily declines among older groups (U.S. Federal Bureau of Investigation 1988). 
Given the apparent strength of this adolescent surge in shoplifting (and larceny in general), it is surprising how few criminologists have tried to explain it. Nettler (1984, p. 103) states that "no current theory of criminogenesis accounts for it." Even extensive studies of juvenile delinquency (e.g., Johnson 1979) typically have focused on variations in behavior among adolescents, rather than asking, Why adolescence?

To begin with, adolescents are prohibited from purchasing certain items, and this may prompt them to steal items an adult could simply purchase. This will be discussed later in the article. More broadly, adolescents' apparently high rate of shoplifting relative to adults may be simply a function of maturation. At least since the time of Freud, we have associated human maturation with an increased ability to delay immediate gratification-with weighing the long-run consequences, social impact, and morality of one's actions. This view has received more recent empirical support from researchers such as Kohlberg (1976) and Burris (1983). Our data, as well as those of Klemke (1982) and Kraut (1976), suggest that many individuals may simply grow out of shoplifting as they enter adulthood.

However, if shoplifting were purely a function of immaturity, one would expect the highest rate of shoplifting to occur among young children, who show an even lower state of moral development and impulse control than do adolescents (Kohlberg 1976; Moschis 1987), yet this does not seem to be the case. This again begs the question, Why adolescence?

One explanation is that adolescence is not merely the last stage in a steady process of maturation from birth to adulthood, but is often a convulsive, stressful transition between the relative calms of childhood and adulthood. Hall (1904) wrote of the "Sturm und Drang" of adolescence. More recently, Erikson (1968) has focused on the "identity confusion" faced by adolescents, whose rapidly changing bodies may make them feel like strangers to themselves, and who may face for the first time the two major self-defining choices of occupation and mate. Marcia (1967) also notes that adolescents often may attempt to abandon the unquestioning acceptance of their parents' ideology and try to forge an ideology of their own. Perhaps in this period of confusion and conflict, adolescents are more inclined to experiment with deviant behaviors such as shoplifting.

Adolescents' high level of shoplifting may also be a consequence of increased opportunity. As juveniles age, the frequency of their independent shopping trips increases steadily, while trips with parents start declining after about age 10 (McNeal 1987). By about the tenth grade, adolescents' independent store visits exceed those made in the company of their parents; at this age, nearly 25 percent of American adolescents list "going to the mall to shop and hang out" as a fa- vorite after-school activity (Hayward 1989). As noted by Reynolds and Wells (1977), many adolescents make a quantum leap in independence at age 16, at which time they are typically permitted both to drive and to work for the first time. This also happens to be the approximate age at which adolescent shoplifting appears to peak.

Thus, it may be adolescents' sudden opportunity to shoplift, combined with a still immature (although advanced beyond that of young children) sense of responsibility and moral development, that leads to a surge in shoplifting behavior. When these factors are combined with the apparent increase in American adolescents' materialism (U.S. Department of Education 1988), we may have at least a partial explanation of why so many adolescents shoplift.

\section{The Perceived Reasons for Adolescent Shoplifting}

Factor Analysis. Several of our analyses involved adolescents' own perception of the reasons for adolescent shoplifting. Prior to performing these analyses, we felt it would be useful to seek a simpler structure in our reason-perception data. Toward that end, we entered the original 15 items into a factor analysis. The initial factors were determined by a principal components analysis, and then the factors were rotated (by the varimax method) to simplify the factor structure. (For a detailed discussion of this method, see Harman 1967.) Next, we calculated factor scores for each respondent and used these for the rest of the analysis. Using factor scores had several advantages. It distilled the 15 items into a small number of uncorrelated, normalized factors, easing the interpretability of subsequent analyses.

The results of the factor analysis are presented in Table 1. As can be seen, four factors emerged. Each of these four factors had an eigenvalue greater than 1.0 , and together they accounted for 64.4 percent of the total variance in the original 15 items.

The first factor clearly reflects perceptions of an experiential reason for adolescent shoplifting. All of the items loading strongly on this factor involve an attraction to novelty or risk in the experience of shoplifting.

The second factor clearly captures perceptions of a social reason for shoplifting. All of the items loading on this factor refer to friends.

Both the third and fourth factors reflect a desire for the product itself as a reason for shoplifting: all seven items loading strongly on one of these factors relate to product acquisition. However, the two factors seem to represent different types of product acquisition reasons. Factor 4 seems to capture a purely economic reason for shoplifting. Its most heavily loading item ("want an item, but don't want to pay for it") reflects the same coldly economic reasons that Kraut 
TABLE 1

FACTOR ANALYSIS OF PERCEIVED REASONS FOR SHOPLIFTING, FACTOR LOADING MATRIX

\begin{tabular}{|c|c|c|c|c|}
\hline Individual items & $\begin{array}{c}\text { Factor I } \\
\text { (experiential) }\end{array}$ & $\begin{array}{c}\text { Factor II } \\
\text { (peer) }\end{array}$ & $\begin{array}{c}\text { Factor III } \\
\text { (contraband) }\end{array}$ & $\begin{array}{l}\text { Factor IV } \\
\text { (economic) }\end{array}$ \\
\hline Need the item badly & -.25 & .09 & .32 & .55 \\
\hline $\begin{array}{l}\text { Want an item, but } \\
\text { don't want to pay } \\
\text { for it }\end{array}$ & .27 & .13 & .05 & .75 \\
\hline $\begin{array}{l}\text { Want to have items } \\
\text { to sell to others }\end{array}$ & .20 & .14 & .09 & .70 \\
\hline Want to see if could & & & & \\
\hline get away with it & .75 & .22 & .05 & .19 \\
\hline Just for fun & .86 & .20 & .08 & .10 \\
\hline $\begin{array}{l}\text { For excitement } \\
\text { Just to see what it's }\end{array}$ & .85 & .20 & .10 & .10 \\
\hline like & .74 & .28 & .16 & .03 \\
\hline $\begin{array}{l}\text { Because friends are } \\
\text { doing it }\end{array}$ & .27 & .76 & .07 & .19 \\
\hline $\begin{array}{l}\text { Because friends } \\
\text { dare them to do it }\end{array}$ & .26 & .83 & .10 & .14 \\
\hline $\begin{array}{l}\text { Want to please } \\
\text { friends }\end{array}$ & .22 & .82 & .13 & .10 \\
\hline $\begin{array}{l}\text { Because a friend } \\
\text { needs the item }\end{array}$ & -.05 & .38 & .61 & .10 \\
\hline $\begin{array}{l}\text { Because friends } \\
\text { want them to } \\
\text { steal }\end{array}$ & .18 & .79 & .21 & .07 \\
\hline $\begin{array}{l}\text { Because they are } \\
\text { told they can't } \\
\text { have it }\end{array}$ & .08 & .21 & .61 & .26 \\
\hline $\begin{array}{l}\text { Because they can't } \\
\text { legally buy the } \\
\text { item }\end{array}$ & .18 & .10 & .54 & .40 \\
\hline $\begin{array}{l}\text { Because they might } \\
\text { be embarrassed } \\
\text { to buy the item }\end{array}$ & .20 & -.05 & .77 & -.06 \\
\hline
\end{tabular}

NOTE.-Salient factor loadings are underlined.

(1976) found among his college shoplifters, who stole simply to "acquire goods at a minimum cost." Another item also reflects a purely economic reason: stealing merchandise to resell it.

The third factor again captures a desire for the merchandise, but reflects not so much an unwillingness to pay as an effort to obtain, surreptitiously, forbidden products. Three of the four heavily loading items directly reflect this (i.e., shoplifting a product because they are "told they can't have it," "can't legally buy it," or are "embarrassed to buy it"). Because of this content, we will label this factor "contraband." The emergence of a contraband reason, distinct from the economic reason, was unanticipated. In all the writings about shoplifting, it has seldom been suggested that shoplifters might steal a coveted item not to avoid payment, but to avoid embarrassment or restrictions on purchase. In one of the few allusions to this possible motive, Cameron $(1964$, p. 20) suggests that the frequent theft of sex and marriage books may be due to embarrassment about their purchase. In ad-
TABLE 2

\begin{tabular}{|c|c|c|c|c|}
\hline $\begin{array}{l}\text { Perceived } \\
\text { reason }\end{array}$ & $\begin{array}{l}\text { Shoplifters' } \\
\text { mean factor } \\
\text { score }\end{array}$ & $\begin{array}{l}\text { Nonshoplifters' } \\
\text { mean factor } \\
\text { score }\end{array}$ & $\begin{array}{c}\text { Test } \\
\text { statistic }\end{array}$ & $\begin{array}{l}\text { Statistical } \\
\text { significance }\end{array}$ \\
\hline Experiential & .01 & .00 & $t=-.13$ & NS \\
\hline Peer & -.11 & .07 & $t=3.53$ & $p<.001$ \\
\hline Contraband & .13 & -.08 & $t=-4.06$ & $p<.001$ \\
\hline Economic & .12 & -.08 & $t=-3.83$ & $p<.001$ \\
\hline
\end{tabular}

dition, a few of Klemke's respondents mentioned a similar reason for shoplifting.

The Perceptions of Shoplifters versus Nonshoplifters. Table 2 contrasts the shoplifting reason perceptions of the adolescent shoplifters with those of their nonshoplifting counterparts. As can be seen, the shoplifters themselves are significantly less likely to feel that peer pressure is an important reason for adolescent shoplifting $(t=3.53, p<.001)$. However, they place a significantly heavier emphasis on the economic $(t=-3.83, p<.001)$ and contraband $(t$ $=-4.06, p<.001)$ reasons than do the nonshoplifters.

It is intriguing that those with the most firsthand experience with shoplifting (i.e., the shoplifters themselves) were the least impressed with the peer pressure explanation of its cause. As mentioned earlier, adolescent shoplifters are much more likely to know other shoplifters, and they tend to shoplift in groups (Baumer and Rosenbaum 1984). The common interpretation for this (e.g., Moore 1983) has been that peer pressure is a major cause of adolescent shoplifting. However, there may be other equally plausible interpretations. For example, adolescents who are already shoplifting may simply be attracted to each other as "birds of a feather" or may find it convenient to work in tandem and seek out like-minded accomplices. Cameron (1964) notes that some shoplifters work in teams of two or more, one distracting store personnel and the other stealing the merchandise.

Knowing other shoplifters may also facilitate vicarious learning that crime may, in fact, pay. Nettler notes $(1989$, p. 30$)$ that "when individuals see others stealing with impunity, they are likely to follow." As mentioned earlier, the actual odds of getting caught while shoplifting are quite low (Griffin 1984), and the chances of getting booked, convicted, and punished are even lower. People who know other shoplifters (or see them in the act) may learn this and be tempted to join in. Johnson (1979, p. 35) cites several studies in reporting that nonoffenders tend to overestimate the actual chance of getting caught and punished for crimes, while "those with greater criminal involve- 


\section{TABLE 3}

SHOPLIFTER CHARACTERISTICS CORRELATED WITH PERCEIVED REASONS FOR ADOLESCENT SHOPLIFTING

\begin{tabular}{|c|c|c|c|c|}
\hline Shoplifter characteristic & $\begin{array}{l}\text { Experi- } \\
\text { ential }\end{array}$ & Peer & $\begin{array}{l}\text { Contra- } \\
\text { band }\end{array}$ & Economic \\
\hline \multicolumn{5}{|l|}{ Sex: } \\
\hline $\begin{array}{l}\text { Males' mean factor } \\
\text { score }\end{array}$ & -.04 & $-.07^{\star}$ & .02 & $.08^{*}$ \\
\hline $\begin{array}{l}\text { Females' mean factor } \\
\text { score } \\
\text { Grade (linear }\end{array}$ & .07 & .13 & -.06 & -.14 \\
\hline correlation) & $.10^{\star \star}$ & $-.14^{\star \star \star}$ & $-.13^{\star \star}$ & .07 \\
\hline $\begin{array}{l}\text { Occupational status } \\
\text { (linear correlation) }\end{array}$ & .06 & -.02 & -.02 & $-.09^{\star}$ \\
\hline $\begin{array}{l}\text { Rule-breaking behavior } \\
\text { (linear correlation) }\end{array}$ & $.19^{\star \star \star}$ & $-.10^{*}$ & $.12^{\star \star}$ & .05 \\
\hline
\end{tabular}

ment are more realistic in their perceptions of the chances of punishment and report lesser expectations of being caught or brought to justice." He goes on to note that "personal experiences with getting caught or getting away with an illegal act-and hearing similar stories from friends-exert perhaps the greatest influence on perceptions of risk."

Seeing others shoplift (and get away with it) may also alter adolescents' perceptions of the wrongness of the crime, creating the impression that everybody does it.

Our adolescent shoplifters were more likely than nonshoplifters to emphasize the product acquisition reasons (economic and contraband) for retail theft. In emphasizing these reasons, the shoplifters may be reflecting a different type of peer pressure than has typically been emphasized in the shoplifting literature. Although most shoplifters did not endorse the view of previous writers (e.g., Moore 1983) that adolescents feel direct peer pressure to perform the act of shoplifting (perhaps as a group initiation rite), adolescent shoplifters may feel social pressure to obtain certain products (e.g., the "right" garment or record, or illicit alcohol or tobacco). If these adolescents are unwilling or unable to purchase these products, this may be an indirect spur to shoplift.

Perceptions among Categories of Shoplifters. Next, we examined how perceptions of shoplifting differed among different categories of adolescent shoplifters. As can be seen in Table 3, there were some distinct patterns. For example, adolescent shoplifters who emphasized the experiential reasons for this crime tended to show a general tendency toward misbehavior. This echoes Zuckerman's (1979) finding that, while economically oriented thieves often seem well behaved, excitement-oriented offenders often show a pattern of disruptive behavior.
The shoplifters most likely to emphasize the social reasons for shoplifting were female and early adolescents. This is consistent with past findings of a stronger peer orientation among female adolescents (Moschis 1987; Smith 1979; for a dissenting view, see Maccoby and Jacklin 1974) and among younger adolescents (Moschis 1987; Piaget 1932).

Contraband was most likely to be emphasized by younger shoplifters, perhaps because these shoplifters are likely to face a longer list of products that are forbidden by law, their parents, or the store. Finally, shoplifters of lower social class were slightly more likely to see the reasons for shoplifting as economic.

Shoplifters' Perceptions and What They Steal. There were some interesting relationships between shoplifters' perceptions of the crime and what they stole. As shown in Table 4, economically oriented shoplifters showed a consistent pattern of stealing the most expensive products. This may reflect their general economic orientation and, in particular, may reflect a small number of shoplifters who are stealing for resale. (One of the items loading on the economic factor was "want to sell the item.") Contraband-oriented shoplifters were more likely than average to steal the forbidden products, cigarettes and alcohol. This is not surprising, since these are products that adolescents are prohibited from purchasing. Shoplifters who emphasized the experiential reasons for the crime were also more likely than average to steal alcohol and tobacco. The reasons for this are less clear, but may reflect these shoplifters' general tendency toward misbehavior, which we will discuss later.

\section{Comparing Adolescent Shoplifters and Nonshoplifters}

Next, we contrasted adolescent shoplifters and nonshoplifters on several demographic and behavioral variables. Those results are reported in Table 5.

Shoplifting and Gender. As can be seen in Table 5, most adolescent shoplifters in our survey were male. This finding is consistent with previous self-reports from adolescents (Klemke 1982) and college students (Kraut 1976), yet the popular view is that shoplifting is a female crime (see, e.g., Verrill 1978), a view that has inspired some elaborate theories concerning females' supposed vulnerability to kleptomania and other larcenous impulses (see, e.g., Russell 1973).

A few studies (e.g., Robin 1963; Won and Yamamoto 1968) have shown a slight female majority among apprehended shoplifters; however, most of these studies have focused on adult offenders. According to U.S. government statistics, thievery is strongly male dominated during the teenage years (when male offenders outnumber female by a 2.7:1 ratio) but less so among older groups (e.g., the ratio is 
TABLE 4

PRODUCTS SHOPLIFTERS STEAL CORRELATED WITH PERCEIVED REASONS FOR ADOLESCENT SHOPLIFTING

\begin{tabular}{|c|c|c|c|c|c|}
\hline \multirow[b]{2}{*}{ Product stolen } & \multirow{2}{*}{$\begin{array}{l}\text { Number of respondents } \\
\text { shoplifting product }\end{array}$} & \multicolumn{4}{|c|}{ Correlations } \\
\hline & & Experiential & Peer & Contraband & Economic \\
\hline \multicolumn{6}{|l|}{ Big-ticket products: ${ }^{a}$} \\
\hline Clothing & 80 & .00 & $-.14^{\star \star \star}$ & $.11^{\star \star}$ & $.10^{\star \star}$ \\
\hline Sporting goods & 58 & $.08^{*}$ & $-.08^{*}$ & .04 & $.15^{\star \star \star}$ \\
\hline Records & 93 & .02 & $-.10^{\star \star}$ & .05 & $.11^{\star \star}$ \\
\hline \multicolumn{6}{|l|}{ Forbidden products: ${ }^{\mathrm{b}}$} \\
\hline Alcoholic beverages & 75 & $.08^{*}$ & $-.09^{\star}$ & $.10^{\star \star}$ & $.10^{\star \star}$ \\
\hline Cigarettes & 83 & $.08^{\star}$ & $-.10^{\star \star}$ & $.08^{\star}$ & .01 \\
\hline \multicolumn{6}{|l|}{ Other products: } \\
\hline Candy & 525 & .01 & -.06 & .01 & $.09^{\star}$ \\
\hline Health products & 79 & .01 & $-.09^{\star}$ & .06 & .01 \\
\hline School supplies & 188 & -.03 & .00 & .03 & .04 \\
\hline Books and magazines & 146 & .05 & .04 & .06 & $.07^{\star}$ \\
\hline Toys & 106 & -.01 & $-.11^{\star \star}$ & $.09^{\star}$ & .06 \\
\hline
\end{tabular}

a Typical unit price exceeds $\$ 5.00$.

b State law prohibits sale to anyone under 21 (alcohol) and 17 (cigarettes)

${ }^{*} p<.05$.

${ }^{\star \star} p<.01$.

${ }^{\star \star \star} p<.001$.

$2: 1$ in the late $20 \mathrm{~s}$ and $1.5: 1$ by age 50 ; U.S. Federal Bureau of Investigation 1988). Thus, we would expect females to constitute a higher percentage of adult shoplifters than of adolescent shoplifters.

Further, reports of female-dominated shoplifting have typically come from stores in which most shoppers are female. For example, Robin (1963) reported that 60.7 percent of the shoplifters apprehended in three department stores were female; however, Warner (1979) found that 67 percent of all department store shoppers were female. Thus, even among adults, a given male shopper is probably more likely to shoplift than a given female shopper, and, among adolescents, males constitute a solid majority of shoplifters.

Why is this so? To begin with, males generally show a stronger tendency than females to bend or break rules. This is reflected in crime statistics, in unobtrusive observation of driving behavior (Sigelman and Sigelman 1976), and in our own subjects' self-reports

TABLE 5

PROFILING ADOLESCENT SHOPLIFTERS AND NONSHOPLIFTERS

\begin{tabular}{ccccc}
\hline $\begin{array}{c}\text { Adolescent } \\
\text { characteristic }\end{array}$ & $\begin{array}{c}\text { Shop- } \\
\text { lifters }\end{array}$ & $\begin{array}{c}\text { Nonshop- } \\
\text { lifters }\end{array}$ & $\begin{array}{c}\text { Test } \\
\text { statistic }\end{array}$ & $\begin{array}{c}\text { Statistical } \\
\text { significance }\end{array}$ \\
\hline $\begin{array}{c}\text { Sex (percentage } \\
\text { male) }\end{array}$ & 63.6 & 48.3 & $\chi^{2}=62.86$ & $p<.001$ \\
$\begin{array}{c}\text { Family occupational } \\
\text { status (mean) }\end{array}$ & 51.04 & 52.08 & $t=.89$ & NS \\
$\begin{array}{c}\text { Rule-breaking } \\
\text { behavior (mean) }\end{array}$ & 2.51 & 2.18 & $t=11.17$ & $p<.001$ \\
\hline
\end{tabular}

of general rule-breaking behavior, on which male adolescents scored significantly higher $(\bar{X}=2.36)$ than females $(\bar{X}=2.25 ; t=3.66, p<.001)$. This tendency can probably be explained at least partially by the different social norms for the two sexes. Females may be socialized to be more conforming and compliant, while "hell-raising" behavior is tolerated more in boys; thus, young males' deviances are often dismissed with the statement "boys will be boys," but we seldom hear "girls will be girls." Whether there are also biological reasons for such gender differences is less clear. For reviews of research on gender differences in behavior, see Deaux (1985) and Maccoby and Jacklin (1974).

Shoplifting and Family Occupational Status. As shown in Table 5, we found no relationship between family occupational status and adolescent shoplifting. While this result deviated from that of Klemke (who did find a small negative relationship), it is not totally surprising. In recent years there has been a rethinking of the relationship between social class and deviance. Early sociologists of deviance tended to rely on police arrest statistics, which almost invariably showed a much higher crime rate among lower social classes; thus, many early theories (see, e.g., Merton 1938) were basically attempts to explain this phenomenon. This thinking started to change with the emergence of studies of middle-class crimes, such as embezzlement, employee theft, and, to some extent, shoplifting (e.g., Cameron 1964; Cressy 1950; Sutherland 1949). Cameron notes that such crimes are usually handled by companies' private security personnel, who are typically more interested in recovering 
property than in arrests and convictions. Few of these cases are reported to the police, especially those involving affluent offenders. Cameron (1964) found security personnel reluctant to tail and apprehend affluent suspects, since stores have greater fears of false arrest suits from customers who can afford highpriced lawyers.

Lacking class biases, self-report studies have typically shown much weaker (or nonexistent) relationships between social class and deviance than have official statistics. Braithwaite (1981) found that 83 percent of police data studies showed a significant relationship between delinquency and socioeconomic status, compared to only 38 percent of the self-report studies.

Why isn't adolescent theft substantially more common among the lower social classes? As discussed earlier, several of the reasons believed to lie behind adolescent shoplifting (e.g., the experiential and contraband reasons) have little to do with family income or social class. Further, even shoplifters who are motivated by a simple desire for the merchandise tend to steal not necessities (à la Jean Valjean's loaf of bread) but luxuries. Cameron (1964, p. 164) notes that adult female shoplifters typically "do not steal merchandise which they can rationalize purchasing: household supplies, husband's clothes, children's wear. But beautiful luxury goods for their own personal use can be purchased legitimately only if some other member of the family is deprived." Similarly, the adolescent shoplifters in our and other studies have typically stolen luxury items, like candy and records. Even some fairly affluent consumers may covet more luxuries than they can afford to purchase.

Shoplifting and Other Rule Breaking. Table 5 indicates that adolescent shoplifters reported a significantly higher level of rule breaking in general than nonshoplifting adolescents. This relationship has not been explicitly examined in previous studies. However, some previous researchers have revealed implicit views on this issue. For example, Nettler's (1984, 1989) view that most people are contingently honest would seem to imply that what differentiates shoplifters from nonshoplifters is primarily circumstantial, that is, being in the wrong place at the wrong time, where temptation, low risk, and a suitably anonymous target present themselves. Other writers (e.g., Johnson 1979) seem to view shoplifting as part of a pattern of behavior that is peculiar to certain individuals. Nettler's circumstantial argument is compelling, but our results suggest that Johnson's view may also contain an element of truth. We suspect that, while situational temptations are a spur to shoplifting, some individuals are especially susceptible to such temptation.

Discriminant Analysis. Finally, we estimated a discriminant function to compare shoplifters and nonshoplifters. The discriminating variables included adolescents' demographics (grade, sex, and socioeconomic status), rule-breaking behavior, and perceptions of the reasons for this crime. The nonlinear relationship between grade and shoplifting was captured by coding the former as a dummy variable (grades 9 and $10=1$, other grades $=0$; for a discussion of the appropriateness of dummy variables in discriminant analysis, see Dillon and Westin 1982).

The discriminant function was statistically significant $\left(\chi^{2}=141.6, p<.0001\right)$ and correctly classified 68 percent of the respondents. The most important variables contributing to this function were rulebreaking behavior, which correlated with the overall discriminant function at $r=.79$, and sex $(r=.54)$. The other discriminating variables, in descending order of importance in the function, were the peer factor $(r=-.23)$, the contraband factor $(r=.23)$, the economic factor $(r=.23)$, grade $(r=.16)$, occupational status $(r=-.05)$, and the experiential factor $(r$ $=.03$ ). Thus, adolescents' patterns of rule-breaking behavior and gender appear to be the most useful variables (among those studied) in discriminating between shoplifters and nonshoplifters.

\section{CONCLUSION}

Adolescent shoplifting is a troubling and pervasive aspect of consumer behavior but has attracted very little previous consumer research. This study has presented both empirical findings and conceptual discussion that we hope will shed some light on this phenomenon. In concluding, we will highlight a few issues that we feel are particularly interesting and worthy of future research.

We speculated earlier in this article that adolescents' high rate of shoplifting is probably due in part to their greater opportunity to shoplift, relative to younger age groups. In addition, shoplifting opportunities for today's adolescents may exceed those of previous generations of adolescents. The suburban shopping mall appears to have emerged as a favorite gathering place for American teenagers; this is reflected both in surveys of adolescents (e.g., Hayward 1989) and in recent media depictions of adolescent life (e.g., the film Fast Times at Ridgemont High). Future research should explore the role of stores and shopping centers as focal points in adolescents' social lives and, in particular, should examine the relationship between "malling" and adolescent shoplifting.

Another conclusion from our study is that peers may play a more complex role in adolescent shoplifting than has previously been supposed. Although several writers have suggested that shoplifters feel direct peer pressure to steal, we found that the adolescent shoplifters themselves were relatively unimpressed with this explanation. Future research should explore alternative explanations for the group nature of ado- 
lescent shoplifting. For example, the simple knowledge of peers' successful shoplifting behavior, even in the absence of pressure to join in, may reduce perceptions of risk, tempting one to engage in the behavior. In addition, knowledge of shoplifting in one's immediate peer group may alter the perceived norms of acceptable behavior, making the behavior seem less bad. Further, adolescent shoplifters may feel social pressure to obtain certain products, and this social pressure may be an indirect spur to shoplift. Future research should examine how these (and other) phenomena may mediate the relationship between adolescents' peer interactions and shoplifting.

Future research might also explore the effect of a store's image on consumers' likelihood of shoplifting from it. As noted earlier, retail trends away from personal service and local ownership may make stores seem more distant and impersonal, thereby making consumers feel less guilty about stealing from them. In the 1950s, Martineau (1958) noted that consumers often attribute personalities to certain retail stores, and Stone (1954) found cases in which some consumers actually felt protective of stores that they believed were owned by some actual person in their local community. Manufacturers have often attempted to humanize their images through advertising, sometimes to great effect. For example, Marchand (1985) reports that the fictitious Betty Crocker once received bushels of mail. While retailers' advertising has typically emphasized a more economic, price-oriented appeal, it would be interesting to explore the effects of more personal advertising (e.g., Mr. Kuppenheimer, or Ben and Jerry) not only on store patronage, but on consumers' ethical behavior toward stores.

Finally, it would be worthwhile to explore the possible connection between shoplifting and the changing values of American consumers. A variety of writers (e.g., Ewen and Ewen 1982; Marchand 1985) have noted the subtle shift in values that has attended the emergence of our modern consumer society. As observed by Marchand (1985, p. 234) this trend has been encouraged by much of modern consumer advertising, which has "invited readers to a new "logic of living' in which the older values of discipline, character-building, self-restraint and production-oriented achievement were subordinated to the new values of pleasure, external appearance, and achievement through consumption."

In a recent $J C R$ article, O'Guinn and Faber (1989) painted a disturbing picture of compulsive buyers, whose addiction to consumption brings immeasurable harm to themselves and the ones they love. Perhaps compulsive buyers and shoplifters are both casualties of the consumer age, for whom the allure of "achievement through consumption" overwhelms such traditional values as frugality and honesty. Consumer researchers must continue to explore the con- sequences, both positive and negative, of our consumption-oriented culture.

\section{[Received July 1989. Revised April 1990.]}

\section{REFERENCES}

Baumer, Terry and Dennis Rosenbaum (1984), Combating Retail Theft: Programs and Strategies, Stoneham, MA: Butterworth.

Bellenger, Danny, Dan Robertson, and Elizabeth Hirschman (1978), "Impulse Buying Varies by Product," Journal of Advertising Research, 18 (December), 1518.

Belson, W. (1975), Juvenile Theft: The Causal Factors, New York: Harper \& Row.

Berman, Barry and Joel Evans (1989), Retail Management: A Strategic Approach, New York: Macmillan.

Blair, Ed, Seymour Sudman, Norman Bradburn, and Carol Stocking (1977), "How to Ask Questions about Drinking and Sex: Response Effects in Measuring Consumer Behavior," Journal of Marketing Research, 14 (August), 316-321.

Braithwaite, J. (1981), "The Myth of Social Class and Criminology Reconsidered," American Sociological Review, 46 (February), 36-57.

Burris, V. (1983), "Stages in the Development of Economic Concepts," Human Relations, 36 (September), 791812.

Cameron, M.O. (1964), The Booster and the Snitch: Department Store Shoplifting, New York: Free Press.

Clinard, Marshall and Robert Meier (1979), Sociology of Deviant Behavior, New York: Holt, Rinehart \& Winston.

Cole, Catherine (1989), "Deterrence and Consumer Fraud," Journal of Retailing, 65 (Spring), 107-120.

Cressey, Donald (1950), "The Criminal Violation of Financial Trust," American Sociological Review, 15 (December), 742 .

Deaux, K. (1985), "Sex and Gender," Annual Review of Psychology, 36, 49-81.

Dillon, William and Stuart Westin (1982), "Scoring Frequency Data for Discriminant Analysis: Perhaps Discrete Procedures Can Be Avoided," Journal of Marketing Research, 19 (February), 44-56.

Duncan, Otis (1976), "A Socioeconomic Index of Occupations," in Occupations and Social Status, ed. Albert J. Reiss, Jr., New York: Free Press.

Erikson, Erik (1968), Identity: Youth and Crisis, New York: Norton.

Ewen, Stuart and Elizabeth Ewen (1982), Channels of Desire: Mass Images and the Shaping of American Consciousness, New York: McGraw-Hill.

Fact Sheet: Results of Gallup Youth Survey (1980), New York: National Retail Merchants Association.

Featherman, David L. and Robert M. Hauser (1978), Opportunity and Change, New York: Academic Press.

Griffin, Roger (1984), "Walking Off with Billions," Security Management, 28 (August), 70-72.

Hall, G. Stanley (1904), Adolescence, New York: Appleton.

Hardt, Robert and Sandra Hardt (1977), "On Determining the Quality of the Delinquency Self-Report Method," 
Journal of Research in Crime and Delinquency, 14 (July), 247-261.

Harman, Harry H. (1967), Modern Factor Analysis, Chicago: University of Chicago Press.

Hayward, Susan (1989), Personal communication. [Ms. Hayward is vice-president of Yankelovich, Clancy \& Shulman.]

Johnson, Richard (1979), Juvenile Delinquency and Its Origins, Cambridge: Cambridge University Press.

Klemke, Lloyd W. (1982), "Exploring Adolescent Shoplifting," Sociology and Social Research, 67 (1), 59-75.

Klokis, Holly (1985), "Confessions of an Ex-shoplifter," Chain Store Age Executive, 61 (February), 15-18.

Kohlberg, Lawrence (1976), "Moral Stages and Moralization: The Cognitive-Developmental Approach," in Moral Development and Behavior: Theory, Research and Social Issues, ed. T. Lickona, New York: Holt, Rinehart \& Winston.

Kraut, Robert E. (1976), "Deterrent and Definitional Influences on Shoplifting," Social Problems, 25 (February), 358-368

Maccoby, E. and C. Jacklin (1974), The Psychology of Sex Differences, Stanford, CA: Stanford University Press.

Marchand, Roland (1985), Advertising the American Dream, Berkeley: University of California Press.

Marcia, James (1967), “Ego Identity Status: Relationship to Change in Self-Esteem, General Maladjustment and Authoritarianism," Journal of Personality, 35 (February), $118-133$.

$\rightarrow$ Martineau, Pierre (1958), "The Personality of the Retail Store," Harvard Business Review, 36 (January-February), 47

May, David (1978), "Juvenile Shoplifters and the Organization of Store Security: A Case Study in the Social Construction of Delinquency," International Journal of Criminology and Penology, 6 (May), 137-160.

McNeal, James (1987), Children as Consumers, Lexington, MA: Lexington.

Merchandising and Operating Results of Department and Speciality Stores (1987), New York: National Retail Merchants Association.

Merton, Robert (1938), "Social Structure and Anomie," American Sociological Review, 3 (October), 672-682.

Moore, Richard (1983), "College Shoplifters: A Rebuttal of Beck and McIntire," Psychological Reports, 53 (December), 1111-1116.

Moschis, George P. (1987), Consumer Socialization: A Life Cycle Perspective, Lexington, MA: Lexington.

Nettler, Gwynne (1984), Explaining Crime, New York: McGraw-Hill.

- (1989), Criminology Lessons, Cincinnati: Anderson.

O'Guinn, Thomas and Ronald Faber (1989), "Compulsive Buying: A Phenomenological Exploration," Journal of Consumer Research, 16 (September), 147-157.
Peterson, Robert, Gerald Albaum, and Nancy Ridgway (1989), "Consumers Who Buy from Direct Sales Companies," Journal of Retailing, 65 (Summer), 273-286.

Piaget, Jean (1932), The Moral Judgement of the Child, New York: Free Press.

Pistone, Joseph D. and Richard Woodley (1988), Donnie Brasco: An F.B.I. Agent Undercover with the Mafia, New York: New American Library.

Reynolds, Fred and William Wells (1977), Consumer Behavior, New York: McGraw-Hill.

Robin, Gerald (1963), "Patterns of Department Store Shoplifting," Crime and Delinquency, 9 (April), 163172.

Russell, Donald H. (1973), "Emotional Aspects of Shoplifting," Psychiatric Annals, 3 (May), 77-79.

Sigelman, K.W. and L. Sigelman (1976), "Authority and Conformity: Violation of a Traffic Regulation," Journal of Social Psychology, 100 (October), 35-43.

Smigel, Erwin (1970), "Public Attitude toward Stealing as Related to the Size of the Victim Organization," in Crimes against Bureaucracy, eds. Erwin Smigel and H. Lawrence Ross, New York: Van Nostrand Reinhold, $15-28$.

Smith, Douglas (1979), "Sex and Deviance: An Assessment of Major Sociological Variables," Sociological Quarterly, 20 (Spring), 183-195.

Stone, Gregory (1954), "City Shoppers and Urban Identification: Observations on the Social Psychology of City Life," American Journal of Sociology, 60 (July), 36-45.

Sudman, Seymour and Norman M. Bradburn (1974), Asking Questions, San Francisco: Jossey-Bass.

Sutherland, Edwin (1949), White Collar Crime, New York: Dryden.

U.S. Department of Commerce (1983), 1980 Census of Population: General Social and Economic Characteristics, Washington, DC: Government Printing Office.

U.S. Department of Education (1988), Youth Indicators 1988: Trends in the Well-Being of American Youth, Washington, DC: Government Printing Office.

U.S. Federal Bureau of Investigation (1988), Uniform Crime Reports for the U.S., Washington, DC: Government Printing Office.

Verill, A.H. (1978), Reducing Shoplifting Losses, Washington, DC: Government Printing Office.

Warner, N.M. (1979), "Shoplifters in Big Store," unpublished M.A. thesis, Department of Sociology, University of Alberta, Edmonton, AB, Canada T6G2R6.

Wilkes, Robert E. (1978), "Fraudulent Behavior by Consumers," Journal of Marketing, 42 (October), 67-75.

Won, George and George Yamamoto (1968), "Social Structure and Deviant Behavior: A Study of Shoplifting," Sociology and Social Research, 53 (October), 44-55.

Zuckerman, Marvin (1979), Sensation Seeking: Beyond the Optimal Level of Arousal, Hillsdale, NJ: Erlbaum. 